\title{
Post-harvest Soil Available Nutrient Status and Microbial Load as Influenced by Graded Levels of Nitrogen and Biofertilizers
}

\author{
Felix Mwiza Mayuni*, G. Karuna Sagar, D. Subramanyam and G. Mohan Naidu \\ Department of Agronomy, S. V. Agricultural College, Tirupati, \\ Andhra Pradesh 517 502, India \\ *Corresponding author
}

\section{A B S T R A C T}

\begin{tabular}{|l|}
\hline Ke y w o r d s \\
Post-harvest Soil, \\
Nitrogen, \\
Biofertilizers
\end{tabular}

\section{Introduction}

Maize (Zea mays L.) is a miracle and industrial crop. It is also called as "queen of cereals" for its relative productive potential among other cereal crops. It is a $\mathrm{C}_{4}$ plant that effectively utilize the inputs and respond well to growth resources. It is an exhaustive and nitropositive crop which needs higher quantity of nitrogen for its maximum yield potential. Nitrogen have its dominant role for growth and development as well as yield of maize. The escalating cost of chemical fertilizer has led to considerably lower net returns and continuous application of fertilizers alone in agricultural system deteriorates the soil health and negatively impacts crop productivity (Kannan et al., 2013). Biofertilizers can either fix atmospheric nitrogen for plant or can mobilize unavailable phosphorus, potassium and zinc to the available pool. Low cost and ecofriendly biofertilizers have tremendous potential for supplying nutrients. Azospirillum is known to fix atmospheric nitrogen and increase grain yield in maize by $10-15$ per cent (Patil et al., 2001). Keeping in view of the above, the field experiment was conducted to identify the optimum nitrogen level along with suitable biofertilizer to kharif maize in sandy clay loam soil. 


\section{Materials and Methods}

A field experiment was conducted in maize during kharif, 2019 at wetland farm of S.V. Agricultural College, Tirupati in a randomized block design with factorial concept and replicated thrice. The soil of the experimental field was sandy clay loam with available nitrogen of $251 \mathrm{~kg} \mathrm{ha}^{-1}$, available phosphorus (180 kg ha $\left.{ }^{-1}\right)$, available potassium $\left(234 \mathrm{~kg} \mathrm{ha}^{-1}\right)$ and available zinc (3.21 ppm). The initial soil microbial load viz., bacteria (21 x $10^{6} \mathrm{CFU} \mathrm{g}^{-1}$ soil), fungi $\left(3 \times 10^{3} \mathrm{CFU} \mathrm{g}-\right.$ ${ }^{1}$ soil) and actinomycetes $\left(7 \times 10^{5} \mathrm{CFU} \mathrm{g}^{-1}\right.$ soil). The treatment consisting three levels of nitrogen viz., 75, 100 and $125 \%$ recommended dose of nitrogen $(\mathrm{RDN})$ and five biofertilizers viz., Azospirillum, phosphorus solubilizing bacteria (PSB), potassium solubilizing bacteria (KSB) and zinc solubilizing bacteria $(\mathrm{ZnS})$ and combined application of Azospirillum + PSB + KSB + $\mathrm{ZnS}$ each $5 \mathrm{~kg} \mathrm{ha}^{-1}$. Recommended dose of nitrogen was fixed based on soil test value. All biofertilizers were applied at $5 \mathrm{~kg} \mathrm{ha}^{-1}$ to soil. Rest of the package of practices were adopted as per the package of practices of Acharya N.G. Ranga Agricultural University. Post-harvest soil available nitrogen (Subbiah and Asija 1956), available phosphorus (Olsen et al., 1956), available potassium (Jackson, 1973) and zinc (Tandon, 1993) were estimated. Soil microbial load of soil viz., bacteria, fungi and actinomycetes were estimated by serial dilution plate count technique (Pramer and Schemidt, 1965).

\section{Results and Discussion}

Grain yield of maize was significantly influenced with application of different nitrogen levels and biofertilizers as well as their interaction (Table 1). Application of 125 $\%$ RDN resulted in higher grain yield, which was at par with $100 \%$ RDN. This might be due to better growth and yield attributes with higher dose of nitrogen. The increase in grain yield due to application of $125 \%$ RDN was 16.44 per cent compared to $75 \% \mathrm{RDN}$. Similar results were also reported by Athokpam et al., (2017) and Mohammadi et al., (2017). The lowest grain yield was obtained with application of $75 \%$ RDN due to sub-optimal dose of nitrogen. The highest grain yield was obtained with combined application of Azospirillum + PSB + KSB + $\mathrm{ZnS}$ each applied $5 \mathrm{~kg} \mathrm{ha}^{-1}$, which was at par with application of Azospirillum and PSB alone each $5 \mathrm{~kg} \mathrm{ha}^{-1}$.

Table.1 Interaction effect of nitrogen levels and biofertilizers on grain yield of maize during kharif, 2019

\begin{tabular}{|l|c|c|c|c|}
\hline \multicolumn{1}{|c|}{ Treatment } & \multicolumn{3}{c|}{ Recommended dose of nitrogen (\%) } \\
\hline Biofertilizers & 75 & 100 & 125 & Mean \\
\hline Azospirillum & 5376 & 6120 & 5364 & 5620 \\
\hline Phosphorus solubilizing bacteria (PSB) & 4764 & 5568 & 5460 & 5264 \\
\hline Potassium solubilizing bacteria (KSB) & 3912 & 4428 & 5172 & 4504 \\
\hline Zinc solubilizing bacteria (ZnS) & 3228 & 4836 & 5316 & 4460 \\
\hline Azospirillum + PSB + KSB + ZnS & 5412 & 5640 & 5844 & 5632 \\
\hline Mean & 4538 & 5318 & 5431 & \\
\hline
\end{tabular}

$\mathrm{SEm} \pm \mathrm{CD}(\mathrm{P}=0.05)$

Nitrogen levels (N) 133386

Biofertilizers (B) 171499

Interaction (N x B) 297864 
Table.2 Post-harvest available nutrient status and microbial load of soil as influenced by nitrogen levels and biofertilizers in maize during kharif, 2019

\begin{tabular}{|c|c|c|c|c|c|c|c|}
\hline \multirow[t]{2}{*}{ Treatment } & \multicolumn{4}{|c|}{ Post-harvest nutrient status $\left(\mathrm{kg} \mathrm{ha}^{-1}\right)$} & \multicolumn{3}{|c|}{ Soil microbial load } \\
\hline & $\begin{array}{l}\text { Available } \\
\text { nitrogen }\end{array}$ & $\begin{array}{c}\text { Available } \\
\text { phosphorus }\end{array}$ & $\begin{array}{l}\text { Available } \\
\text { potassium }\end{array}$ & $\begin{array}{l}\text { Available } \\
\text { zinc }\end{array}$ & $\begin{array}{c}\text { Bacteria } \\
\left(10^{6} \mathrm{CFU} \mathrm{g}^{-1}\right)\end{array}$ & $\begin{array}{c}\text { Fungi } \\
\left(10^{3} \mathrm{CFU} \mathrm{g}^{-1}\right)\end{array}$ & $\begin{array}{c}\text { Actinomycetes } \\
\left(10^{5} \mathrm{CFU} \mathrm{g}^{-1}\right)\end{array}$ \\
\hline \multicolumn{8}{|l|}{ Factor I: Nitrogen levels } \\
\hline $\mathrm{N}_{1}: 75 \% \mathrm{RDN}$ & 152.7 & 50.6 & 101.2 & 0.42 & 132.5 & 10.6 & 26.5 \\
\hline $\mathrm{N}_{2}: 100 \% \mathrm{RDN}$ & 193.2 & 64.1 & 128.1 & 0.61 & 163.9 & 13.0 & 32.3 \\
\hline $\mathrm{N}_{3}: 125 \% \mathrm{RDN}$ & 219.3 & 69.1 & 137.5 & 0.80 & 230.5 & 15.4 & 38.5 \\
\hline $\mathrm{SEm} \pm$ & 1.03 & 0.52 & 0.99 & 0.01 & 4.77 & 0.3 & 0.8 \\
\hline $\mathrm{CD}(\mathrm{P}=0.05)$ & 2.98 & 1.50 & 2.89 & 0.03 & 13.89 & 0.9 & 2.4 \\
\hline \multicolumn{8}{|l|}{ Factor II: Biofertilizers } \\
\hline $\mathbf{B}_{1}:$ Azospirillum & 186.5 & 61.7 & 123.3 & 0.60 & 169.9 & 13.4 & 33.6 \\
\hline $\begin{array}{l}\text { B }_{2}: \text { Phosphorus solubilizing } \\
\text { bacteria (PSB) }\end{array}$ & 182.9 & 60.7 & 121.3 & 0.55 & 161.9 & 12.8 & 31.7 \\
\hline $\begin{array}{l}\mathrm{B}_{3} \text { : Potassium solubilizing } \\
\text { bacteria }(\mathrm{KSB})\end{array}$ & 174.3 & 57.8 & 115.6 & 0.52 & 157.0 & 11.9 & 29.8 \\
\hline $\begin{array}{l}\mathbf{B}_{4}: \text { Zinc solubilizing bacteria } \\
(\mathrm{ZnS})\end{array}$ & 165.7 & 53.6 & 107.1 & 0.60 & 139.7 & 10.9 & 27.2 \\
\hline $\begin{array}{l}\text { B }_{5}: \text { Azospirillum + PSB + KSB } \\
+\mathrm{ZnS}\end{array}$ & 232.6 & 72.6 & 144.0 & 0.77 & 249.9 & 16.0 & 40.0 \\
\hline $\operatorname{SEm} \pm$ & 1.32 & 0.67 & 1.28 & 0.01 & 6.16 & 0.4 & 1.1 \\
\hline $\mathrm{CD}(\mathrm{P}=\mathbf{0 . 0 5})$ & 3.85 & 1.94 & 3.73 & 0.04 & 17.93 & 1.2 & 3.1 \\
\hline Interaction ( $\mathbf{N} \times$ B) & NS & NS & NS & NS & NS & NS & NS \\
\hline
\end{tabular}


These results are in line with the findings of Lakum et al., (2018). Application of $\mathrm{ZnS} 5 \mathrm{~kg}$ $\mathrm{ha}^{-1}$ resulted in lower grain yield. This is possibly due to non-response of zinc solubilizing bacteria. Application of $100 \%$ RDN along with Azospirillum $5 \mathrm{~kg} \mathrm{ha}^{-1}$ produced significantly higher grain yield, which was at par with application of $125 \%$ RDN or $100 \%$ RDN with combined application of Azospirillum + PSB + KSB + $\mathrm{ZnS}$ each $5 \mathrm{~kg} \mathrm{ha}^{-1}$. It clearly indicate that performance of Azospirillum $5 \mathrm{~kg} \mathrm{ha}^{-1}$ found to be more responsive to promote growth and development of maize because of the enhanced mineralization and biological nitrogen fixation.

Post-harvest available nutrient status and soil microbial load was significantly influenced by nitrogen levels and biofertilizers, but their interaction was non-significant (Table 2). The highest values of post-harvest available nutrient status and microbial population viz., bacteria, fungi and actinomycetes were noticed with application of $125 \%$ RDN which might be due to sufficient substrate available for growth and multiplication of microorganisms, which inturn increased the mineralization and availability of nutrients in the soil.

These results are corroborative with the findings of Abdullahi et al., (2014) and Navsare (2107). Combined application of Azospirillum $+\mathrm{PSB}+\mathrm{KSB}+\mathrm{ZnS}$ each applied $5 \mathrm{~kg} \mathrm{ha}^{-1}$ resulted in higher soil available nutrient status due to enhanced mineralization and solubility of insoluble fixed nutrients. The response of Azospirillum $5 \mathrm{~kg} \mathrm{ha}^{-1}$ found to be more responsive than others while zinc solubilizing bacteria was found to be poor. The response of microorganisms are highly location specific. These results are in conformity with the earlier findings of Garcia et al., (2017) and Khambalkar et al., (2017).

\section{References}

Abdullahi, R., Shariff, H.H and Buba, A. 2014. Effect of biofertilizer and organic manure on growth and nutrient content of pearl millet. Journal of Agricultural and Biological Science. 9(10): 351-355.

Athokpam, H., Telem, R.S and Wani, S.H. 2017. Integrated nutrient management for sustainable maize (Zea mays L.) production in acidic soil of Senapati District, Manipur, India. International Journal of Current Microbiology and Applied Sciences. 6(7): 690-695.

Garcia, M.M., Pereira, L.C., Braccini, A.L., Angelotti, P., Suzukawa, A.K., Marteli, D.C.V., Felber, P.H., Bianchessi, P.A and Dametto, I.B. 2017. Effect of Azospirillum brasilense on growth and yield components of maize grown at nitrogen limiting conditions. Revista de Ciências Agrárias. 40(2): 353-362.

Jackson, M.C. 1973. Soil Chemical Analysis. Prentice Hall of India. Private limited, New Delhi, 498.

Kannan, L.R., Dhivya, M., Abinaya, D., Krishna, R.L and Krishnakumar, S. 2013. Effect of integrated nutrient management on soil fertility and productivity in maize. Bulletin of Environment, Pharmacology and Life Sciences. 2(8): 61-67.

Khambalkar, P. A., Narendra Singh, Verma, S.K and Shashi S.Y. 2017. Influence of integrated nutrient management on soil fertility and properties of sandy clay loam and relationship with productivity of pearl millet (Pennisetum glaucum) - mustard (Brassica juncea) cropping sequence. International Journal of Chemical Studies. 5(5): 1237-1243.

Lakum, Y.C., Patel, S.H and Mehta, P.V. 2018. Reducing fertilizer requirement 
with the use of biofertilizers in summer pearl millet. Asian Journal of Soil Science. 6(1): 50-66.

Mohammadi, N.K., Pankhaniya, R.M., Joshi, M.P and Patel, K.M. 2017. Influence of inorganic fertilizer, vermicompost and biofertilizer on yield and economic of sweet corn and nutrient status in soil. International Journal of Applied Research. 3(5): 183-186.

Navsare, R.I. 2017. Studies on effect of potassium and zinc solubilizing microorganism on mungbean. M.Sc. (Ag.)Thesis. Marathwada Agricultural University, Badnapur, Maharashtra.

Olsen, S.R., Cole, C.V., Watanabe, F.S and Dean, L.A. 1954. Estimation of available phosphorus in soil by extraction with sodium bicarbonate. United States Department of
Agriculture. Circular number: 939.

Patil, R.K., Goyal, S.N., Vora, M.S and Vaishnav, P.R. 2001. Response of kharif maize to inoculation with Azotobacter and Azospirillum at varying levels of nitrogen. G.A.U. Research Journal. 27(1\&2): 13-17.

Pramer, D and Schmidt, E.L. 1965. Experimental Soil Microbiology. Burgess Publishing Co., Minneapolis.

Subbiah, B.V and Asija, G.L. 1956. Rapid procedure for estimation of available nitrogen in soils. Current Science. 25: 259-260.

Tandon, H.L.S. 1993. Methods of Analysis of Soils, Plant, water and Fertilizers. Fertilizer Development and Consultation Organization. New Delhi. 140 .

\section{How to cite this article:}

Felix Mwiza Mayuni, G. Karuna Sagar, D. Subramanyam and Mohan Naidu, G. 2020. Postharvest Soil Available Nutrient Status and Microbial Load as Influenced by Graded Levels of Nitrogen and Biofertilizers. Int.J.Curr.Microbiol.App.Sci. 9(07): 2548-2552. doi: https://doi.org/10.20546/ijcmas.2020.907.299 